\title{
INFLUENCE OF BIODIESEL ON COMPRESSION IGNition ENGine PERFORMANCE
}

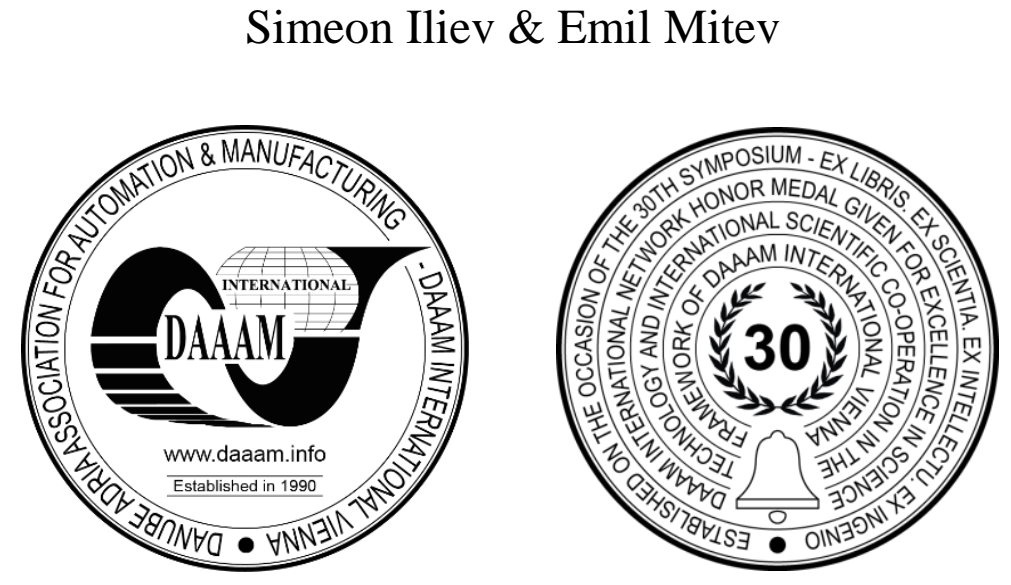

This Publication has to be referred as: Iliev, S[imeon] \& Mitev, E[mil] (2019). Influence of Biodiesel on Compression Ignition Engine Performance, Proceedings of the 30th DAAAM International Symposium, pp.0424-0431, B. Katalinic (Ed.), Published by DAAAM International, ISBN 978-3-902734-22-8, ISSN 1726-9679, Vienna, Austria DOI: $10.2507 / 30$ th.daaam.proceedings.057

\begin{abstract}
In the simulation study, the four-cylinder, four-stroke, direct injection compression ignition engine with an electronically controlled injection system was used. The results obtained from the use of biodiesel were compared to those of pure diesel fuel. The characteristic of maximum power, torque, temperature and pressure were compared One-dimensional simulation of a four-cylinder diesel engine with the help of the AVL Boost software has been done. Comparison of simulated power and torque results in use of biofuel showed that the use of biodiesel causes a drop in power and torque at maximum power $3750 \mathrm{~min}^{-1}$ up $6.5 \%$. At maximum engine torque $1900 \mathrm{~min}^{-1}$, there is a very small drop in power and torque of $0.15 \%$. Power drop and the torque of using biodiesel is within the expected range of 8 to $10 \%$.
\end{abstract}

Keywords: Biofuel; Diesel Engine; Engine Performance; Engine Simulation; AVL

\section{Introduction}

The fossil fuel resources are dwindling day by day. Oil is becoming increasingly scarce and soon will not be able to meet the numerous demands, arising mainly from the transport sector. Decline of available oil reserves and more stringent environmental regulations have motivated the global interest in other energy sources. Environmental legislation has demanded lower emissions of harmful products over the last decade combustion that the internal combustion engine may release into the environment. One way reduction of environmental pollution is also the use of alternative fuels [1], [2]. If transport fleets operated completely with biofuels, it would strengthen the sustainable energy system. The current tendency in energy consumption will create an energy crisis in the near future. Renewable and carbon-neutral biodiesel is the way to achieve economic sustainability and environmental protection.

The primary alternate to fossil fuels is biodiesel. Biodiesel is an alternate energy source for numerous reasons: being renewable, the molecular structure is highly biodegradable with minimal combustion toxicity; compared to diesel, it gives off negligible emissions of sulphates, aromatic hydrocarbons along with minute quantities of smoke containing carbon dioxide (CO2), carbon monoxide (CO) and particulates; it can be used in diesel engines without any modifications [3], [4], [5], it contains more oxygen which aids the complete combustion of the fuel, leading to decrease in emissions [6], it is suitable for use in modern diesel engines (blended with diesel or pure biodiesel) [7], it has better lubricating properties and reduces engine wear [8], its cetane number is higher than that of conventional diesel, biodiesel is rapidly 
biodegradable and therefore reduces the risk of soil and groundwater contamination in the event of potential spillage during transport. Biodiesels do not contain sulphur, which helps to reduce acid rains and their harmful effects on ecosystems. Another important advantage is that they do not require complex logistics like oil products.

Rapeseed, soybean and palm oils are the most commonly used oils to produce biodiesel, although non edible oils, such as Jatropha, are becoming more important [9].

There are some disadvantages of using biodiesel like cold start problems in low-temperature environment, higher NOx emissions, lower calorific value, higher corrosion in the copper strip and difficulty in fuel pumping due to high viscosity and the biodiesel's cost production is high as compared with diesel. Biodiesel has around 11\% less energy content compared to standard pure diesel and susceptible to water contamination and bacteriological growth.

From the literature review, it was concluded that the influence of biodiesel on compression ignition engine performance have not been investigated sufficiently. For this reason, this study investigated the influence of biodiesel on compression ignition engine performance at different engine speed and compared them with those of the pure diesel.

\section{Exposition}

There are numerous studies on the use of mixtures of biodiesel-diesel in different concentration with compression ignition engines, which show the advantages and some limitations resulting from such a solution. In one of the studies, authors investigated engine characteristics using castor oil biodiesel, coconut oil biodiesel and waste cooking oil biodiesel and its blends on a diesel engine. The experimental results shows that coconut oil biodiesel and waste cooking oil biodiesel show better performance and engine emission characteristics [10]. In another reports on engine performance, combustion and emission on compression ignition engine concluded that biodiesel blends up to $20 \%$ can be used as substitute fuel in diesel engines with slight or no modifications [8], [11]. Another authors [12] has investigated experimentally and numerically Volvo D12C, diesel engine fueled rapeseed methyl ester at different blends. Results showed that the ignition delay was shorter for all blends and engine operating conditions, when compared to Diesel fuel. Other authors [4] found that $\mathrm{CO}$ emissions decrease by almost $50 \%$ when biodiesel is used in compression ignition engines. This test was done on full load conditions. Many researches has shown that the amount of particulate matter emitted is also decreased considerably while biodiesel is used.

Figure 1 shows a four-cylinder diesel engine, developed using the AVL Boost software.

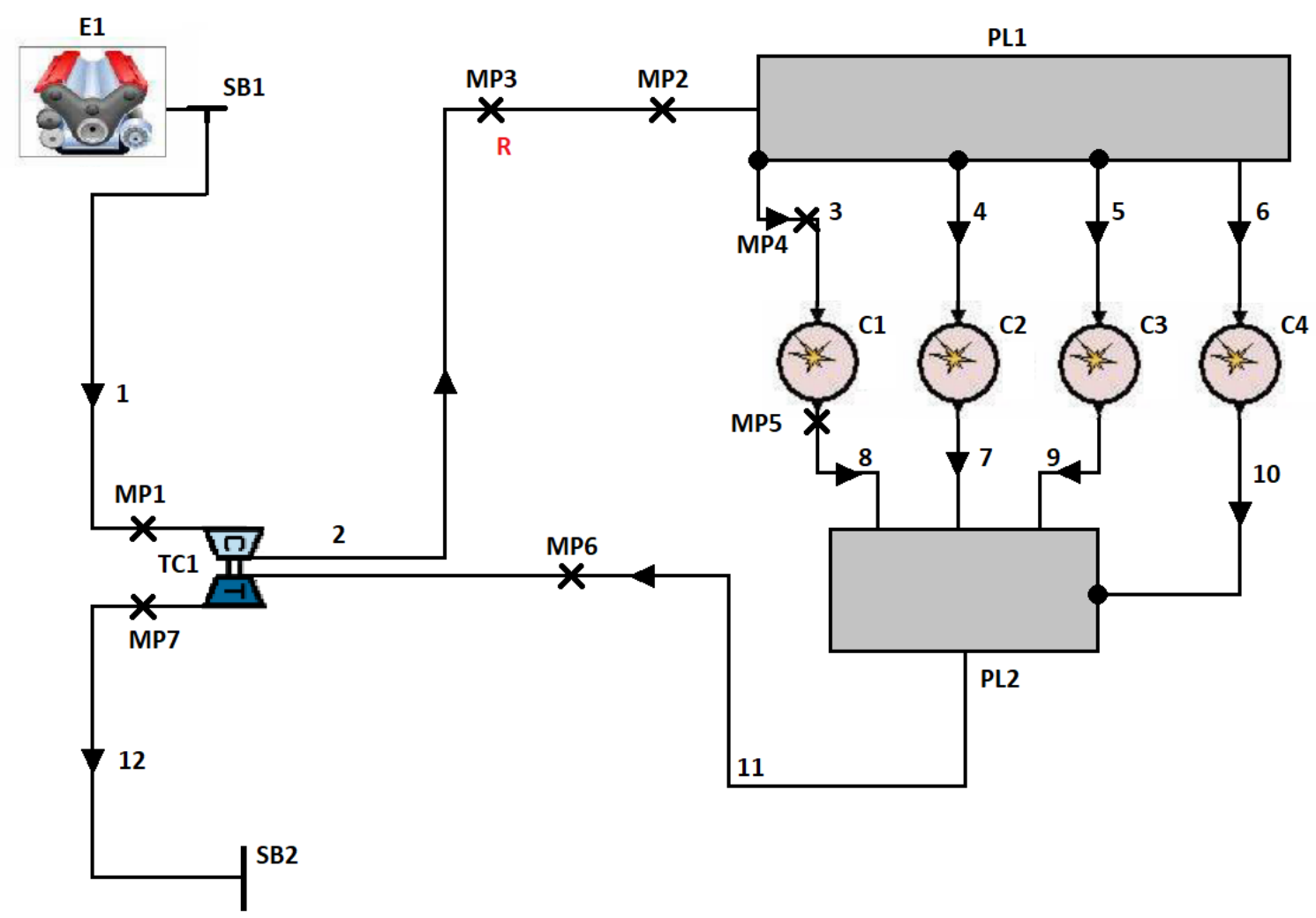

Fig. 1. Four cylinder -cylinder diesel engine model 
The characteristics of the diesel engine used in the study are shown in Table 1. The results of the numerical simulation for diesel in AVL Boost were compared with the basic engine information given in the engine manual and Table 1 (maximum engine power $47 \mathrm{~kW}$ at $3750 \mathrm{~min}^{-1}$, maximum torque of $160 \mathrm{Nm}$ at $1900 \mathrm{~min}^{-1}$ ).

\begin{tabular}{|l|l|}
\hline Description & Value \\
\hline Fuel & Diesel \\
\hline Engine type & Four cylinder \\
\hline Piston diameter [mm] & 76 \\
\hline Piston stroke [mm] & 80,5 \\
\hline Volume [cc] & 1461 \\
\hline Compression ratio & $18,25: 1$ \\
\hline Power [kW] & 47 at $3750 \mathrm{~min}^{-1}$ \\
\hline Maximum torque [Nm] & 160 at $1900 \mathrm{~min}^{-1}$ \\
\hline Fuel injection system & Common rail \\
\hline Number of valves per cylinder & 2 \\
\hline Charging system & Turbocharger \\
\hline Connection Rod Length [mm] & 4,5 \\
\hline
\end{tabular}

Table 1. Characteristics of the diesel engine

In the table. 2 are given some of the basic properties of diesel fuel and biodiesel.

\begin{tabular}{|c|c|c|}
\hline Fuel properties & Diesel & Biodiesel \\
\hline Density at $15{ }^{\circ} \mathrm{C}, \mathrm{kg} / \mathrm{l}$ & $0,82-0,86$ & 0,885 \\
\hline Boiling point, ${ }^{\circ} \mathrm{C}$ & $180-360$ & 322 \\
\hline Viscosity at $40^{\circ} \mathrm{C}, \mathrm{mm}^{2} / \mathrm{s}$ & $2-4,5$ & 4,58 \\
\hline Flash point, ${ }^{\circ} \mathrm{C}$ & $>55$ & $>110$ \\
\hline Temperature of self-ignition, ${ }^{\circ} \mathrm{C}$ & $200-300$ & 167 \\
\hline Ignition delay (ms) & 8,7 & 9,99 \\
\hline Ash, $\%$ & $<0,01$ & $<0,02$ \\
\hline Acidity, mg KOH/100 $\mathrm{cm}^{3}$ & $<5$ & 0,23 \\
\hline Sulfur content, $\%$ & $<0,001$ & 0,01 \\
\hline Temperature of freezing, ${ }^{\circ} \mathrm{C}$ & -5 to -25 & -8 to -20 \\
\hline Ester content & - & 98 \\
\hline Cetane number & $>51$ & $52-65$ \\
\hline Lower combustion heat, $\mathrm{MJ} / \mathrm{kg}$ & 42,5 & $36-68$ \\
\hline Elementary analysis & - & - \\
\hline $\mathrm{C}, \%$ & $76,6-78$ & $86-86,4$ \\
\hline $\mathrm{H}, \%$ & 12,1 & $13,4-14$ \\
\hline $0, \%$ & $10-11$ & - \\
\hline
\end{tabular}

Table 2. Essential properties of diesel and biodiesel

Figure 2 shows the comparison of the engine power from the manual with numerical simulation for diesel fuel at maximum torque $1900 \mathrm{~min}^{-1}$ shows equal values. Value power from the manual is $32 \mathrm{~kW}$ at $1900 \mathrm{~min}^{-1}$, while the result 
of numerical simulation is $31.3 \mathrm{~kW}$. The difference is thus $0.7 \mathrm{~kW}$ or $2.2 \%$. The torque tolerance is slightly larger 3750 $\min ^{-1}$ : in the numerical simulation for diesel, the value of the engine power is $44.9 \mathrm{~kW}$, while the manual states a power of $47 \mathrm{~kW}$. The difference is thus $2.1 \mathrm{~kW}$ or $4.5 \%$.

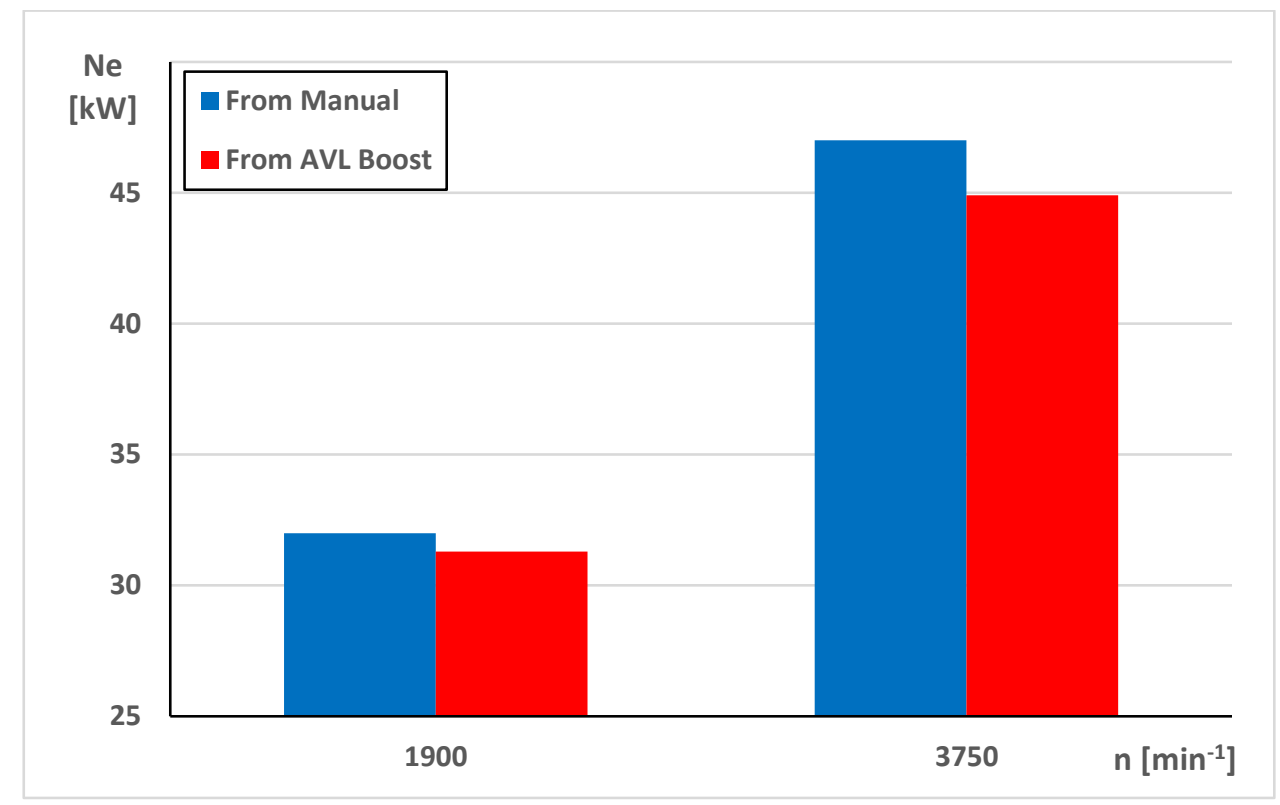

Fig. 2. Comparison of engine power with diesel fuel

The torque from engine manual is $160 \mathrm{Nm}$ at $1900 \mathrm{~min}^{-1}$ (maximum torque) and $120 \mathrm{Nm}$ at $3750 \mathrm{~min}^{-1}$. It is in Figure 3 presented a comparison between manual data and numerical simulation results for diesel fuel. The manual indicates maximum torque $160 \mathrm{Nm}$, the result of the numerical simulation is $2.5 \mathrm{Nm}$ lower. The difference is $1.6 \%$. To higher the difference in torque drop occurs at $3750 \mathrm{~min}^{-1}$ : Numerical simulation result is $4.7 \%$ lower than information in the manual, which states $120 \mathrm{Nm}$.

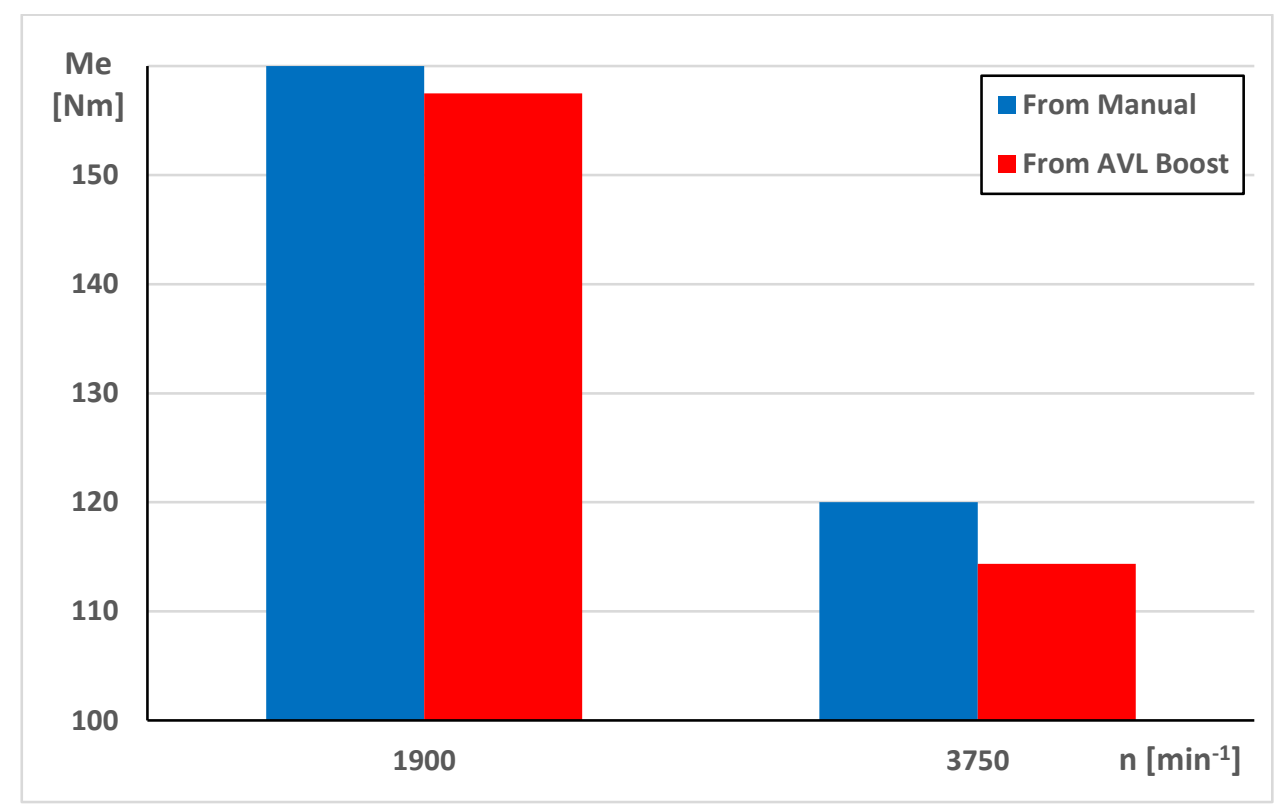

Fig. 3. Comparison of engine torque with diesel fuel

Figure 4 shows a comparison of engine torque when using biodiesel and diesel fuel at $1900 \mathrm{~min}^{-1}$ and $3750 \mathrm{~min}^{-1}$ Based on the results presented, it can be confirmed that a very small difference in the drop is observed of torque at 1900 $\mathrm{min}^{-1}$ for both types of fuel. The difference is $0.24 \mathrm{Nm}$ or $0.15 \%$. Numerical simulations, when comparing biodiesel and diesel, showed that at $3750 \mathrm{~min}^{-1}$ the diesel engine achieves $7.3 \mathrm{Nm}$ more torque than if it had been driven fuel used biodiesel. The engine torque is thus $6.5 \%$ higher when using diesel fuel. The drop is not so great due to higher cetane biodiesel and higher injected masses of fuel that offset the lower fuel value of biodiesel. 


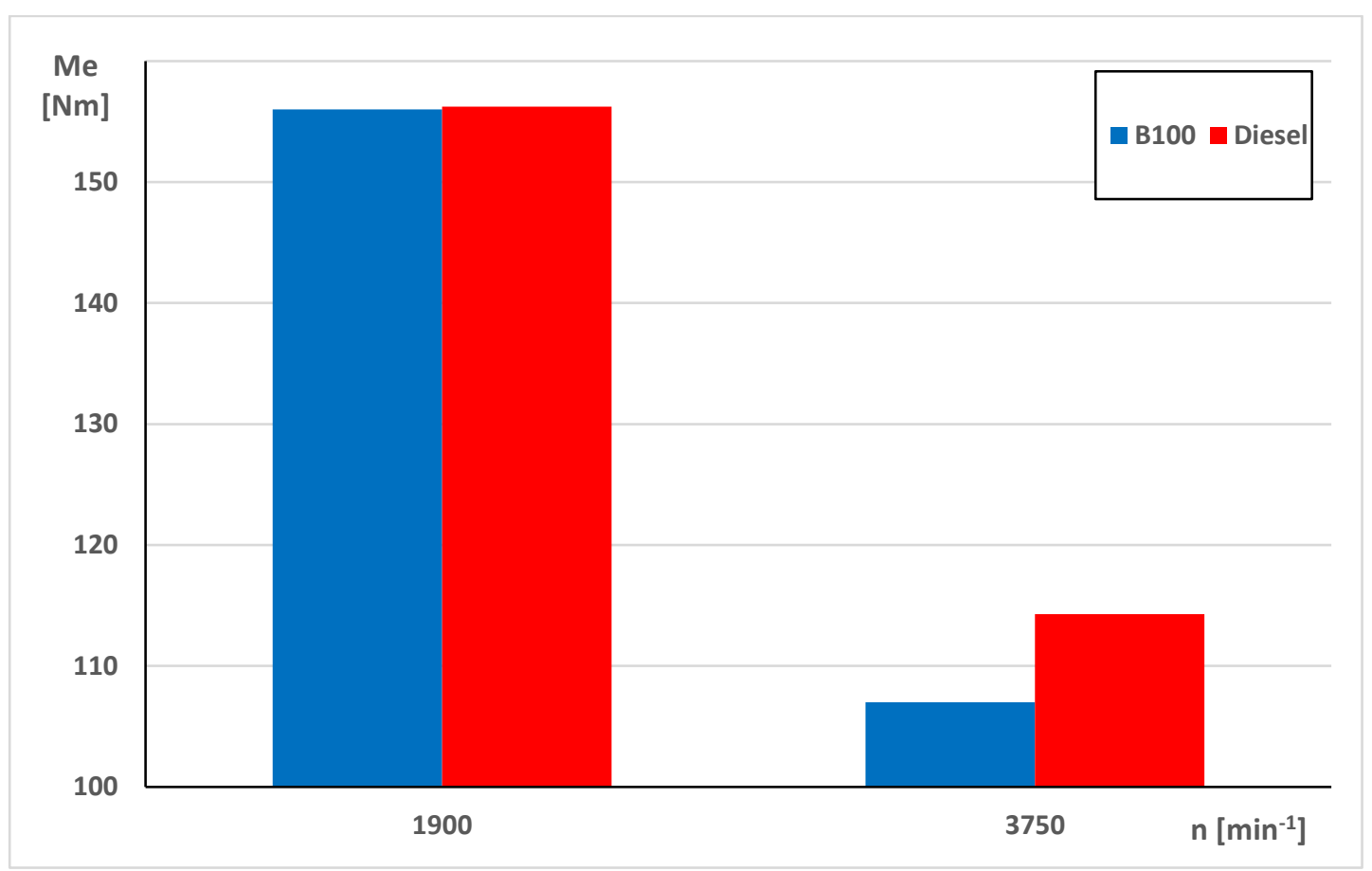

Fig. 4. Comparison of engine torque when using different fuel

Figure 5 and Figure 6 show the in-cylinder pressure variation with biodiesel and diesel fuels at $1900 \mathrm{~min}^{-1}$ and 3750 $\mathrm{min}^{-1}$ engine speed. As can be seen from Figure 5, no major changes were observed in the use of biodiesel in-cylinder pressure variation compared to diesel fuel. At engine speed $1900 \mathrm{~min}^{-1}$ it can be observed that the combustion pressure of biodiesel fuel in range between 360 and 390 degrees of crankshaft rotation is higher on average by $0,5 \mathrm{MPa}$ or $6 \%$ of the combustion pressure of the diesel fuel biodiesel fuel. From Figure 6, which shows the in-cylinder pressure variation at engine speed $3750 \mathrm{~min}^{-1}$, there are no major changes in the use of diesel or biodiesel and range from $0,1 \mathrm{MPa}$ to $1 \%$. This can be explained by the higher density, kinematic viscosity and cetane number compared to diesel. Low cetane number of diesel duel means longer ignition delay, taking more time for fuel to vaporize before combustion starts, which causes a reduction in maximum pressure rise.

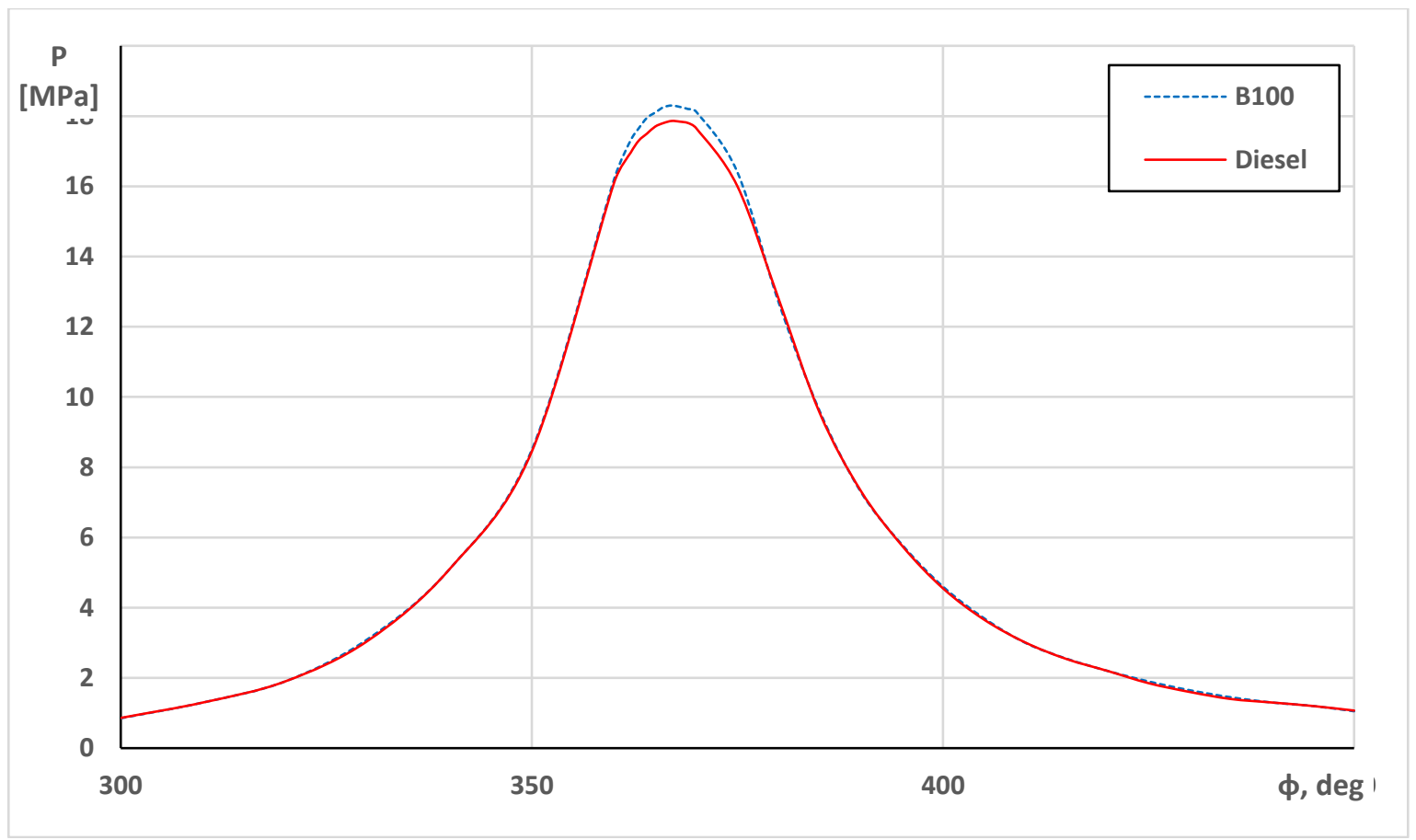

Fig. 5. In-cylinder pressure variation depending on the crankshaft angle, with biodiesel and diesel at $1900 \mathrm{~min}^{-1}$ 


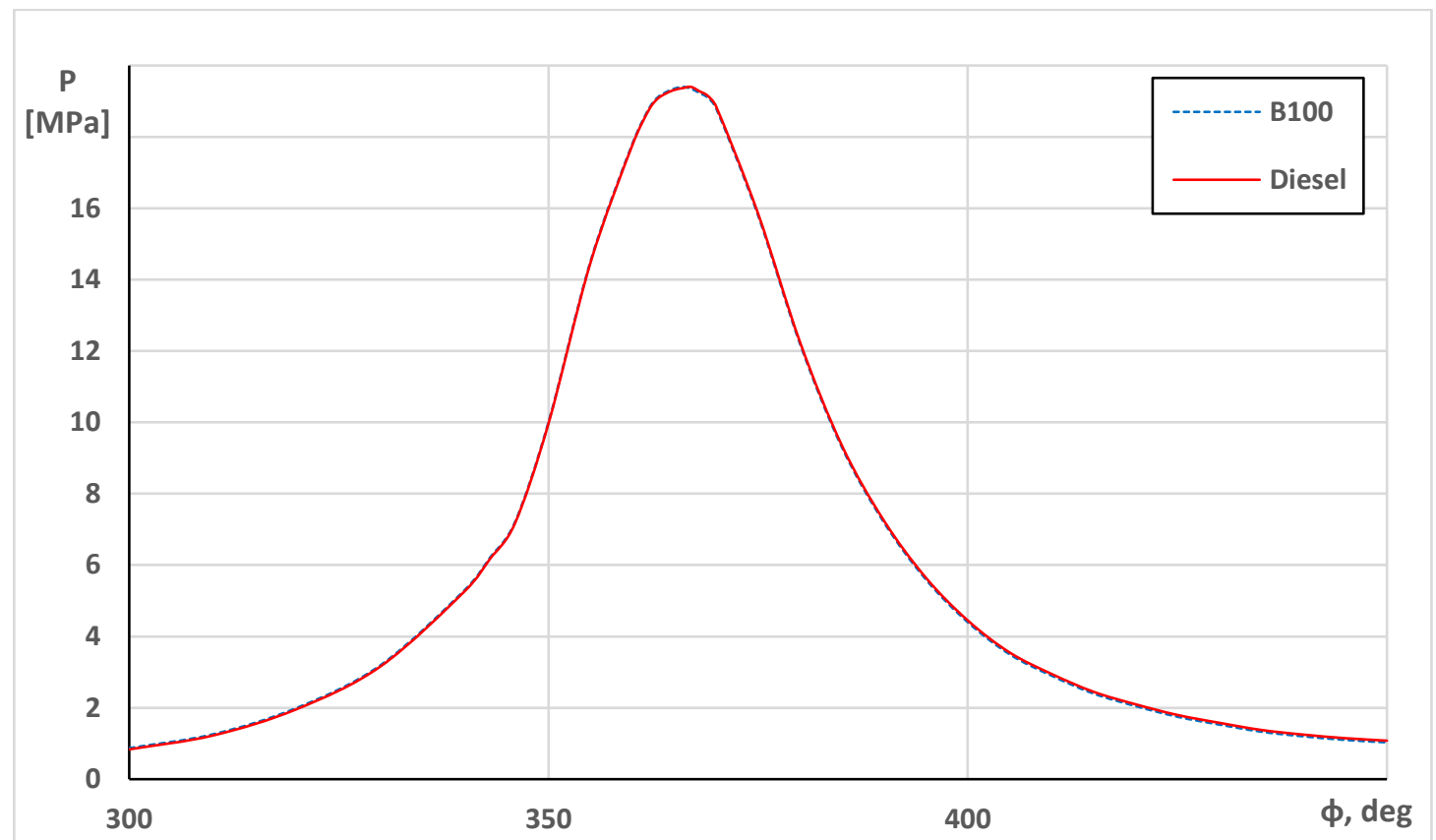

Fig. 6. In-cylinder pressure variation depending on the crankshaft angle, with biodiesel and diesel at $3750 \mathrm{~min}^{-1}$

Various simplifications are used to approximate the heat release characteristic heat release models. For the diesel engine, the model was used in our case Woschni 1978 [13]. Figure 7 shows the amount of heat released at $1900 \mathrm{~min}^{-1}$. From figure we can see that they are maximum the amount of heat released for both compared fuels is relatively the same and does not produce large deviations. The maximum value of $73 \mathrm{~J} /{ }^{\circ} \mathrm{RG}$ is reached at 370 degrees of crankshafts rotation. The use of biodiesel results in a faster increase of the released heat, which is reflected at a higher maximum pressure in the combustion chamber.

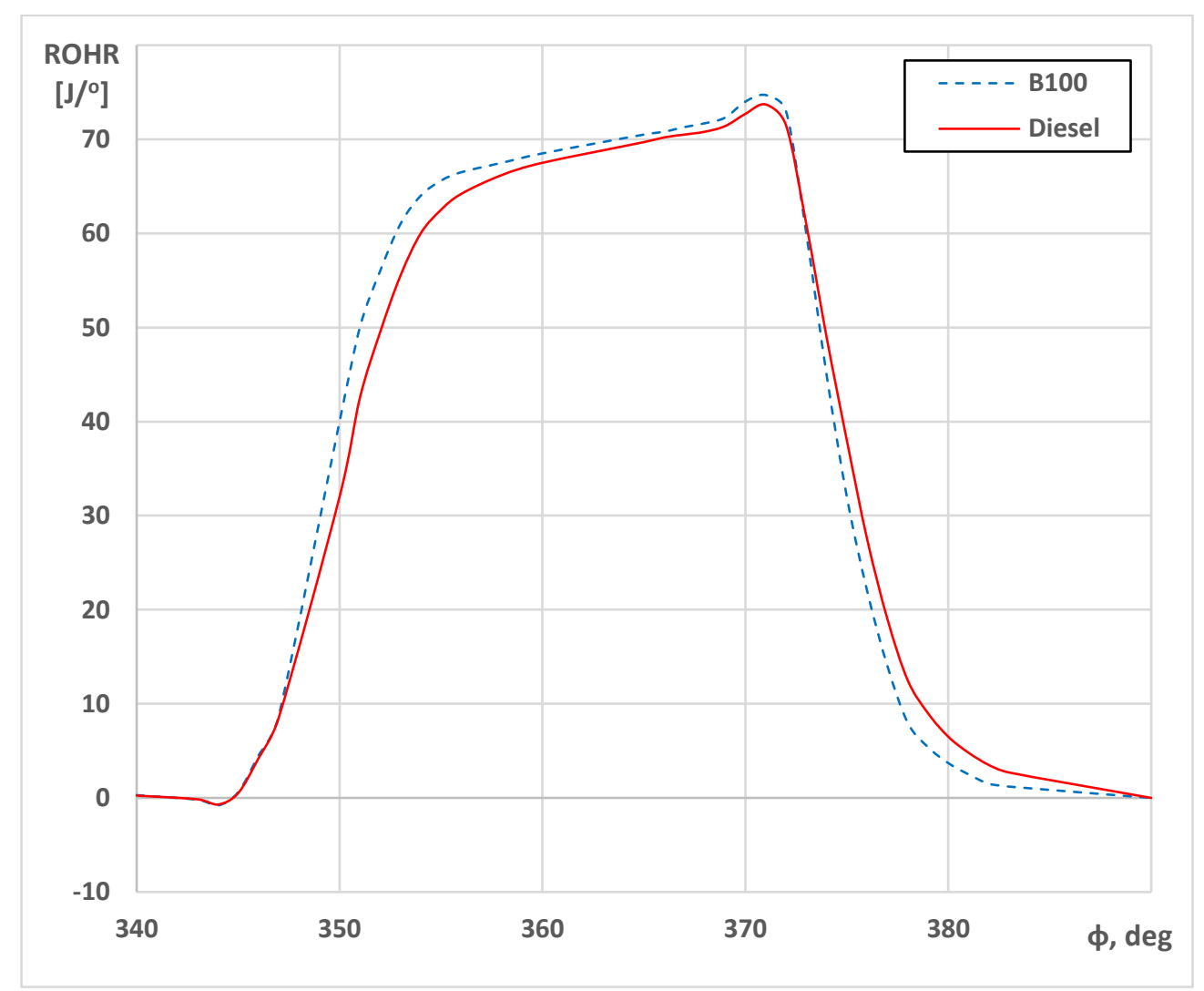

Fig. 7. Amount of heat released depending on the crankshaft angle, with biodiesel and diesel at $1900 \mathrm{~min}^{-1}$ 
Maximum amount of heat released at $3750 \mathrm{~min}^{-1}$ is reached at 370 degrees of crankshaft rotation and for diesel fuel $53 \mathrm{~J} /{ }^{\circ} \mathrm{RG}$ and for biodiesel $51 \mathrm{~J} /{ }^{\circ} \mathrm{RG}$ (Figure 8).

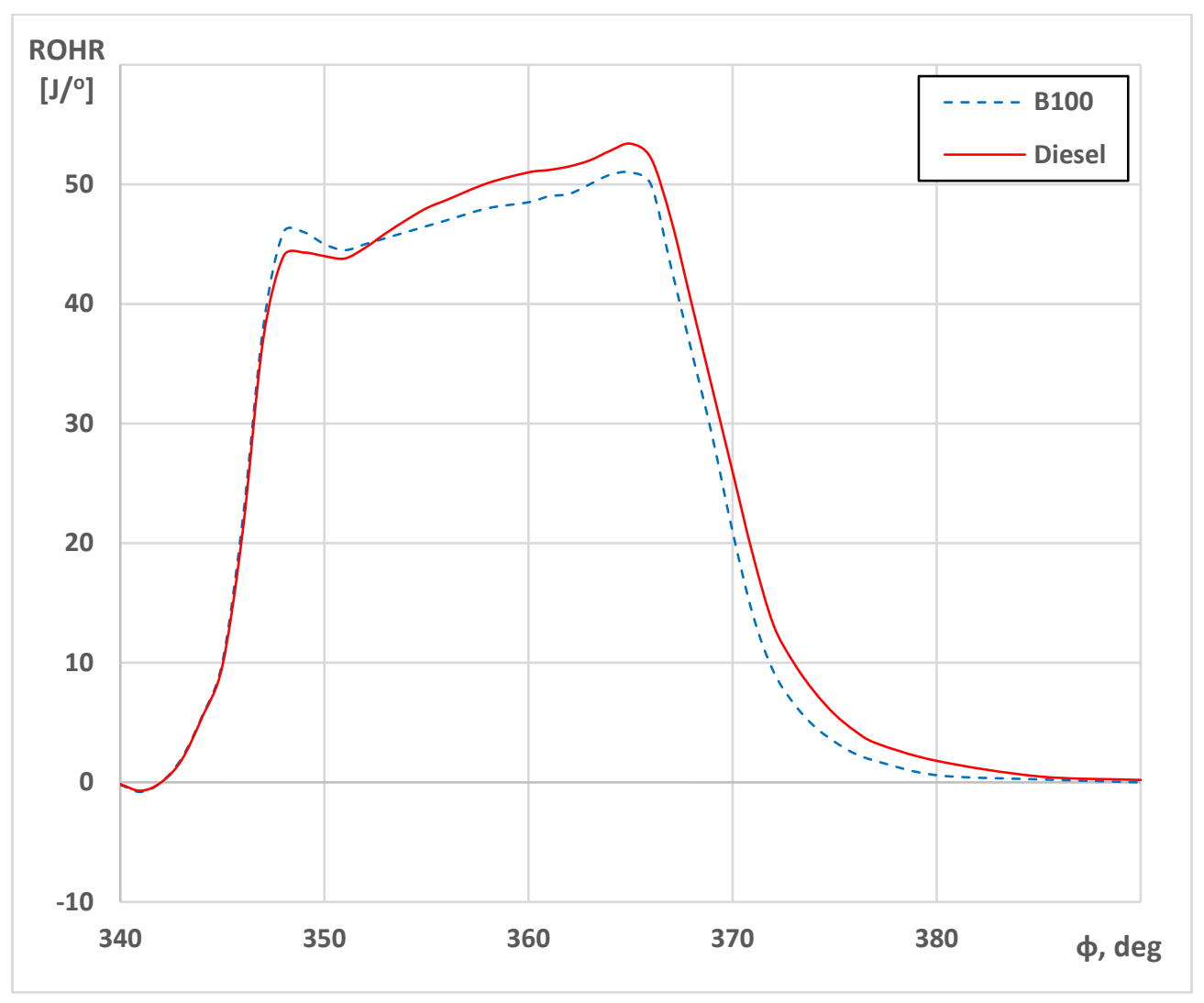

Fig. 8. Amount of heat released depending on the crankshaft angle, with biodiesel and diesel at $3750 \mathrm{~min}^{-1}$

\section{Conclusion}

The main purpose of this study is to investigate the effect of using biodiesel and its influence on compression ignition engine performance. According to the simulation results, it can be concluded that:

1. At engine speed $1900 \mathrm{~min}^{-1}$ it can be observed that the combustion pressure of biodiesel fuel in range between 360 and 390 degrees of crankshaft rotation is higher on average by $0,5 \mathrm{MPa}$ or $6 \%$ of the combustion pressure of the diesel fuel biodiesel fuel. For engine speed $3750 \mathrm{~min}^{-1}$, there are no major changes in the use of diesel or biodiesel and range from $0,1 \mathrm{MPa}$ to $1 \%$. This can be explained by the higher density, kinematic viscosity and cetane number compared to diesel. Low cetane number of diesel duel means longer ignition delay, taking more time for fuel to vaporize before combustion starts, which causes a reduction in maximum pressure rise.

2. The amount of heat released at $1900 \mathrm{~min}^{-1}$ we can see that they are maximum the amount of heat released for both compared fuels is relatively the same and does not produce large deviations. The maximum value of $73 \mathrm{~J} /{ }^{\circ} \mathrm{RG}$ is reached at 370 degrees of crankshafts rotation. The use of biodiesel results in a faster increase of the released heat, which is reflected at a higher maximum pressure in the combustion chamber.

3. Maximum amount of heat released at $3750 \mathrm{~min}^{-1}$ is reached at 370 degrees of crankshaft rotation and for diesel fuel $53 \mathrm{~J} /{ }^{\circ} \mathrm{RG}$ and for biodiesel $51 \mathrm{~J} /{ }^{\circ} \mathrm{RG}$

As the future plan of the experiment team will investigate the influence of biodiesel on compression ignition engine exhaust emissions.

\section{Acknowledgments}

The study was supported by contract of University of Ruse “Angel Kanchev”, № BG05M2OP001-2.009-0011-C01. Support for the development of human resources for research and innovation at the University of Ruse "Angel Kanchev". The project is funded with support from the Operational Program" Science and Education for Smart Growth 2014 - 2020" financed by the European Social Fund of the European Union.

The present document was supported with the financial assistance of the Project 2019-RU-03. 


\section{References}

[1] Iliev, S. (2019). Comparison of Ethanol and Methanol Blending with Gasoline Using Engine Simulation, Biofuels Challenges and opportunities, Mansour Al Qubeissi, IntechOpen, DOI: 10.5772/intechopen.81776.

[2] Iliev, S. (2018). Comparison of Ethanol, Methanol and Butanol Blending with Gasoline and Relationship with Engine Performances and Emissions, Proceedings of the 29th DAAAM International Symposium, pp.0505-0514, B. Katalinic (Ed.), Published by DAAAM International, ISBN 978-3-902734-20-4, ISSN 1726-9679, Vienna, Austria

[3] Azad, A.K.; Rasul M.G.; Giannangelo B. \& Islam R. (2015). Comparative study of diesel engine performance and emission with soybean and waste oil biodiesel fuels. International Journal of Automotive and Mechanical Engineering, 12(1): p. 2866-2881.

[4] Pinzi, S.; Rounce P.; Herreros J.M.; Tsolakis A. \& Dorado M.P. (2013) The effect of biodiesel fatty acid composition on combustion and diesel engine exhaust emissions. Fuel, 104: p. 170-182.

[5] Gad M.S.; El-Araby R.; Abed K.A.; El-Ibiari N.N.; El Morsi A.K. \& El-Diwani G.I. (2018) Performance and emissions characteristics of C.I. engine fueled with palm oil /palm oil methyl ester blended with diesel fuel Egypt. J. Pet., 27 (2), pp. 215-219

[6] Hosseini S.M., Ahmadi R. (2017) Performance and emissions characteristics in the combustion of co-fuel dieselhydrogen in a heavy-duty engine, Appl. Energy 205 911-925, https://doi.org/10.1016/j.apenergy.2017.08.044.

[7] Fazal MA; Haseeb ASMA, Masjuki HH. (2011) Biodiesel feasibility study: an evaluation of material compatibility; performance; emission and engine durability. Renew Sustain Energy Rev; 15(2):1314-24.

[8] Upendra R, Verma T. (2019) Influence of combustion and emission characteristics on a compression ignition engine from a different generation of biodiesel, Engineering Science and Technology, an International Journal, ISSN 22150986, https://doi.org/10.1016/j.jestch.2019.04.003.

[9] Knothe, G.; Gerpen, J. V.; Krahl, J. (2005) The Biodiesel Handbook; AOCS Press: Illinois,

[10] Zareh P.; Zare A. \& Ghobadian B. (2017) Comparative assessment of performance and emission characteristics of castor, coconut and waste cooking based biodiesel as fuel in a diesel engine, Energy, https://doi.org/10.1016/j.energy.2017.08.040.

[11] Tamilselvan P.; Nallusamy N. \& Rajkumar S. (2017) A comprehensive review on performance, combustion and emission characteristics of biodiesel fuelled diesel engines, Renewable Sustainable Energy Rev. 79 1134-1159, https://doi.org/10.1016/j.rser.2017.05.176.

[12] Golovitchev V., Yang J. (2009) Construction of combustion models for rapeseed methyl ester biodiesel fuel for internal combustion engine applications Biotechnol Adv , 27, pp. 641-655

[13] AVL, (2019) AVL Boost Manual. Graz 